\title{
Computer Basic Teaching Reform in Applied Undergraduate Colleges Based on "MOOC"
}

\author{
Xudong Zhang \\ Jilin Engineering Normal University \\ Changchun, Jilin, China, 130052
}

\begin{abstract}
With the development of the Internet, the rapid popularization of MOOC, a new thing, has brought new challenges to the computer basic teaching in applied undergraduate colleges. It is a new research topic for teachers to cope with the impact of "MOOC" on classroom teaching, take part in the teaching process of "MOOC" and improve the learning effect of students. From the "MOOC" classroom, this work mainly studied the principle and mode of computer basic teaching reform in applied undergraduate colleges, and hoped to offer a reference for the development of computer teaching in colleges.
\end{abstract}

Keywords-Computer Teaching; "MOOC" Classroom; Content; Teaching Reform

\section{INTRODUCTION}

"MOOC" is the product in the web's continued evolution and a new teaching method. It is a kind of large-scale open network course for teachers and students around the world to learn by publishing relevant teaching videos on the Internet. "MOOC" has brought impact and change to the computer teaching in applied undergraduate colleges, which makes the computer teaching more humanized.

\section{OVERVIEW ON "MOOC" TEACHING}

"MOOC" (Massive Open Online Course) is a large-scale online open course. As long as you can access the Internet, no matter where you are in the world, you can enjoy the professors of the best teachers in the world's top schools and the high-quality teaching resources in the world's famous universities. "MOOC" has set off a new learning revolution. Compared with traditional classroom teaching, it has the following four significant characteristics [1-2].

First, the diversity of participants. Compared with the traditional classroom teaching, "MOOC" learners do not need to be in school students. It has no restrictions on learners such as region, country, age, education, etc. As long as you have the network, you can do it.

Second, more flexible learning style. "MOOC" meets the needs of different levels for students' individualized autonomous learning. It does not require learners to study together with fixed students at the specified time and place, which is conducive to the development of personality and potential.

Third, online interactivity. The teaching design for "MOOC" is to divide the knowledge points into several related small units, and record "MOOC" teaching video for about 8-12 minutes for each small unit. At the same time, small tests are interspersed between them, so as to meet learners' various learning needs anytime and anywhere. In this way, learners can also choose learning content freely according to their own learning situation and interest points, and enhance the interaction between teachers and students in the teaching process.

Fourth, personalized service based on learning big data. In the whole learning process of each learner, all learning behaviors of each learning object can be automatically recorded by the "MOOC" system. The huge "learning big data" is formed by collecting the relevant data of millions of students' online learning [3]. Next, through macro and micro analysis, data mining, machine learning and other related technologies can be used to find the learning laws contained in "learning big data". Teachers can adjust each teaching link in time and pertinently, and then implement the individualized teaching service of "individualized teaching" in large-scale learning population.

\section{The NeCESSity of "MOOC" TeAChING FOR COMPUTER SPECIALTY IN APPLIED UNDERGRADUATE COLLEGES}

\section{A. Enriching the classroom teaching resources}

The course resources are very important in computer basic teaching based on MOOC. Inner Mongolia Normal University, etc., have set up their own "MOOC" teaching platform through the reform of basic computer teaching, and achieved good teaching results. Southwest Petroleum University classifies and cuts the existing teaching contents by using the university computer basic courses on the "MOOC" platform of China University as online teaching resources. According to the characteristics of different majors and learning needs, classified teaching has achieved good results. This teaching system combines off-line resources with on-site resources and forms a new curriculum system based on the theory of MOOC. It not only realizes the application of traditional university computer basic reform textbooks, but also brings Internet resources into the classroom and expands students' horizons, which injects new vitality into the computer teaching in applied undergraduate colleges.

\section{B. Changing the traditional teaching mode}

The traditional teaching mode is that teachers explain knowledge in class and assign homework after class. Students mainly practice and submit corresponding homework after class, so as to complete the digestion of knowledge in class. 
Obviously, this model can't achieve the goal of teaching reform aimed at cultivating students' computational thinking. In terms of curriculum organization, MOOC takes flipped classroom as its core (i.e., flipping the time in and out of class, teaching and learning). This new teaching mode can make us change the traditional teaching mode of teaching in class and reviewing after class. From the process of training computational thinking to the whole teaching process, it can't only be in the classroom, but also extend to the outside of the classroom [4].

First, students are required to watch the corresponding teaching video through "MOOC", and conduct personalized learning in the way of self or group collaboration to master the basic knowledge. Then, combined with the classroom teaching design, the cultivation of computing thinking ability is achieved. This new flipped teaching mode can effectively overcome the limitation, of course, hours and the disadvantages of students' individual differences. At the same time, it can make teachers fully consider the course positioning and teaching objectives when designing courses. In this new teaching mode, the classroom teaching with the cultivation of computational thinking as the core will become the most important link in the teaching reform. Whether the classroom teaching design can be done well is the key to realize the cultivation of computational thinking.

\section{Paying attention to the students' personality development}

Combined with classroom learning and "MOOC" courses, each student can reasonably arrange time for learning according to their own basis and learning habits. Students with good foundation can selectively learn some learning units, and teachers can also arrange other video resources for learning expansion according to their needs. Students with the poor foundation can watch videos for many times to learn and understand knowledge points. Through this way of learning, the gap between students is reduced, and the demand for classified teaching is ensured.

In the computer "MOOC" teaching in applied undergraduate colleges, students' individualized development is much emphasized. Based on students' needs, MOOC resources are reasonably selected. Combined with the actual training plan and goal requirements, learning objectives and thinking problems are put forward for the corresponding knowledge units, so that students can carry out "MOOC" learning and course discussion [5]. At the same time, the teaching system based on "MOOC" is also based on PPT presentation, which encourages students to discuss and solve problems in groups, tests and records on the "MOOC" platform, fully respects students' main position, and comprehensively stimulates students' subjective initiative in computer learning.

\section{ReseARCH ON COMPUTER BASIC TEACHING MODE BASED ON "MOOC"}

\section{A. Reasonable selection of "MOOC" teaching resources}

On the "MOOC" platform, basic computer teaching in applied undergraduate colleges also shows the following two categories according to the specific teaching ideas of the course.

First, under the guidance of computational thinking, the basic computer courses in applied undergraduate colleges are divided into corresponding modules according to the knowledge system. Taking the module as the mainline, computer technology and its related computer problems and their solutions are introduced. Such resource providers include Xi'an Jiaotong University, Beijing Jiaotong University, etc. The main idea is to strengthen the understanding and application of program design ideas and data processing technology based on understanding computer theory and system principles. Through these preliminary ideas and methods of using computers to solve problems, students' ability to solve and analyze problems is improved, so as to gradually establish the quality of computing thinking. Through the analysis of the course knowledge system and content, it is found that this kind of video has high requirements for students' basic understanding of ability and foundation. Considering the actual level of students in the school, this kind of resource is not suitable for the course resources. Some students with a better foundation can expand their learning outside the class [6].

Second, the course knowledge system is modularized and classified. During the teaching, the students' understanding of computer hardware and software technology and the basic concept of database technology is emphasized. At the same time, computing thinking is properly introduced to explain the relationship between computing thinking, computing technology, and computing culture. The course content and practical problems are combined to gradually penetrate the concept of computing thinking. Taking "MOOC" resources of the National University of Defense Technology and China Agricultural University as examples, the student base of the university is relatively weak. Based on mastering the basic theory and principle of computer, it is necessary to give consideration to the basic level of different students, strengthen the ability of computer application and initially establish the concept of computing thinking.

\section{B. The design of computer basic teaching process}

The teaching mode combines "MOOC" with traditional classroom teaching, as shown in Fig. 1. 


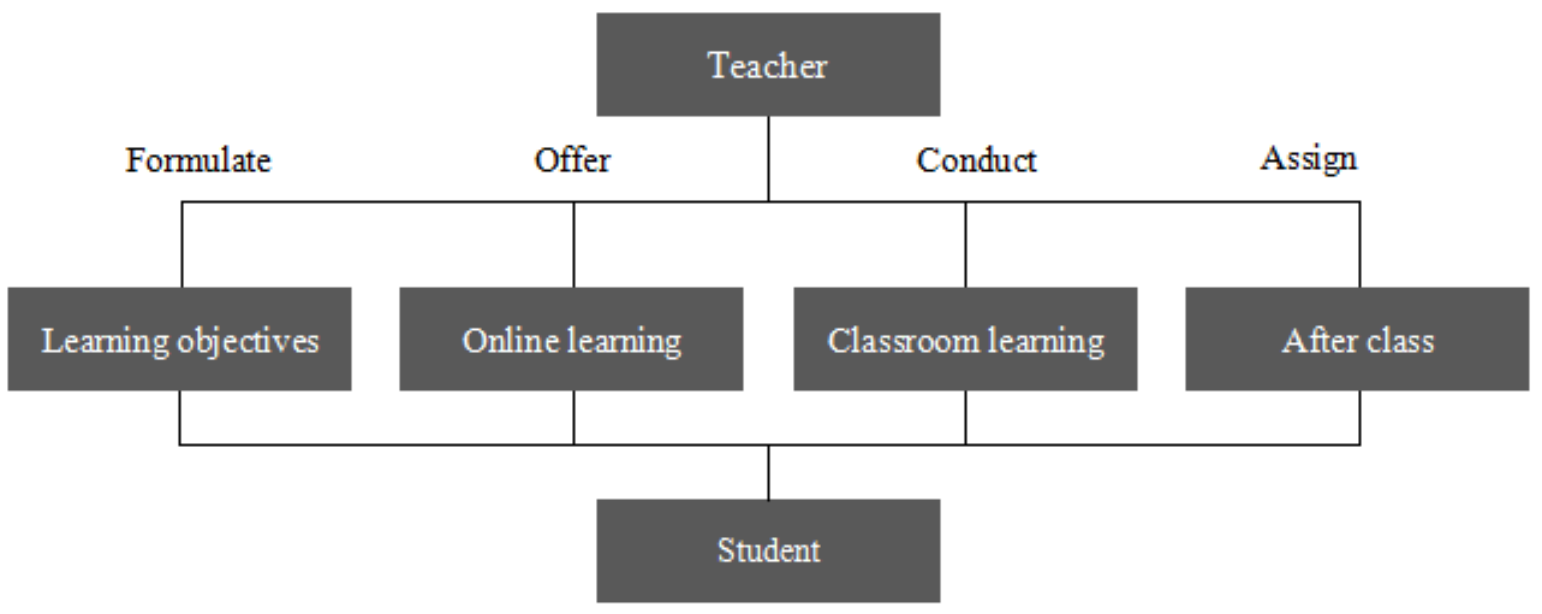

Fig.1. Computer "MOOC" teaching model in applied undergraduate colleges

With the above teaching mode as the guiding ideology, the specific teaching process can be divided into the following parts.

First, the students are divided into three to five learning groups. Before each class, the teacher arranges the video learning content and the questions to be considered. The students take the questions to study independently after class and record the doubts and questions in the learning process.

Second, after learning, one member of each group will report and summarize the learning situation and problems, and discuss the problems raised by the students in class. Everyone can express their own opinions, actively participate in and fully mobilize the enthusiasm of students.

Third, in order to prevent students from being slack and perfunctory in the learning process, if any fraud is found in class discussion and report, the corresponding unit score of the group is zero according to the principle of group co-prosperity and co-punishment.

Fourth, after class discussion and summary, students can use unit tests on "MOOC" resources for self-evaluation after class, and submit the screenshot of the evaluation results to the teacher, who will check the learning effect of students.

During the implementation of this part, the extracurricular expansion part should be combined with real-life cases. For example, students can design seals, make e-newspapers, bookmarks, etc., to make more hands-on and application in the office part, which not only enhances students' interest in learning, but also helps to cultivate computing thinking. The specific teaching settings are shown in Table I.

TABLE I. TEACHING DESIGN OF APPLICATION UNIT BETWEEN MULTIMEDIA AND INTERNET

\begin{tabular}{|c|c|c|c|c|}
\hline Knowledge module & Video unit & Teaching activities & Practice test & After-class expansion \\
\hline \multirow{3}{*}{$\begin{array}{l}\text { Multimedia } \\
\text { technology } \\
\text { foundation }\end{array}$} & $\begin{array}{c}\text { Multimedia basic } \\
\text { concepts and } \\
\text { common media types }\end{array}$ & \multirow{3}{*}{$\begin{array}{l}\text { Group PPT report } \\
\text { presentation, group } \\
\text { discussion, answers } \\
\text { to questions and } \\
\text { difficulties }\end{array}$} & $\begin{array}{l}\text { Use of common } \\
\text { playback tools, }\end{array}$ & \multirow{2}{*}{$\begin{array}{l}\text { Use clip tools to } \\
\text { complete video } \\
\text { production }\end{array}$} \\
\hline & $\begin{array}{l}\text { Multimedia } \\
\text { composition }\end{array}$ & & simple video editing & \\
\hline & $\begin{array}{l}\text { Digital image } \\
\text { processing } \\
\text { foundation } \\
\end{array}$ & & $\begin{array}{l}\text { Use Photoshop to } \\
\text { process personal } \\
\text { photos }\end{array}$ & $\begin{array}{c}\text { Submit image } \\
\text { processing works }\end{array}$ \\
\hline \multirow{3}{*}{$\begin{array}{l}\text { Computer network } \\
\text { and Internet } \\
\text { application }\end{array}$} & $\begin{array}{c}\text { Overview on a } \\
\text { computer network }\end{array}$ & \multirow{3}{*}{$\begin{array}{l}\text { Group PPT report } \\
\text { presentation, group } \\
\text { discussion, answers } \\
\text { to questions and } \\
\text { difficulties }\end{array}$} & $\begin{array}{l}\text { Local area network } \\
\text { and common } \\
\text { equipment, IP } \\
\text { settings, ftp tools }\end{array}$ & \multirow{3}{*}{$\begin{array}{l}\text { Register email, } \\
\text { download video, } \\
\text { network resources }\end{array}$} \\
\hline & $\begin{array}{l}\text { Network architecture } \\
\text { and protocols }\end{array}$ & & $\begin{array}{l}\text { Search engine, } \\
\text { browser, email, }\end{array}$ & \\
\hline & Internet application & & download tool & \\
\hline
\end{tabular}

\section{Building real-time interaction bridge between teachers and students}

"MOOC" advocates the concept of "large-scale opening and sharing". With the help of the Internet platform and advanced human-computer interaction technology, it can offer a richer form of interaction and better realize large-scale interaction. In the computer teaching in applied undergraduate colleges, the interaction links can be designed with the help of the above concepts, which specifically include the following.
The first is the interaction between teachers and students. Teachers and students can interact asynchronously or synchronously. Asynchronous interaction refers to the use of one-to-many forms (i.e., teachers answer questions raised by students for a period of time in a centralized manner). Synchronous interaction refers to teachers answering students' questions in real-time with students during the online period of the forum. 
The second is the interaction between students and students. Students can exchange learning materials and experience by sharing notes of teaching materials, or they can use the way of reviewing homework among students, or they can use social platforms such as QQ group, WeChat, blog, etc., for interactive learning. This kind of interaction is convenient, fast and recordable, which can't be completed in traditional classroom teaching.

The third is the interaction between students and online course resources. "MOOC" course is designed to learn about students' learning status in real-time through embedded test questions in the learning video. After class, there are supporting exercise questions. There are exams in the middle of the course. All these questions are offered with correct and detailed answers online, and students' completion is recorded in time. In many cases, they are automatically evaluated and statistically analyzed. This is actually a process of human-computer interaction. Some courses also offer online experiments, for example, "introduction to computer science", a basic computer course of Harvard University, and offers online virtual software experiments of VM ware, which greatly arouses students' interest in learning and improves learning efficiency.

\section{Realizing multiple online teaching evaluation}

In the process of "MOOC" teaching, the formative evaluation of students can be completed by means of electronic recording and automatic statistical analysis, and the areas that need to be improved in teaching can be analyzed. In the process of computer teaching in applied undergraduate colleges, the evaluation of students can be completed by computers, students, teachers, alumni, etc., including in class tests, after class test and homework and final homework.

The first is in-line testing during the presentation. Many "MOOC" teaching videos are embedded with test questions. These test questions are mainly aimed at the knowledge points explained. They appear immediately after the explanation and require students to solve them in real-time [7]. They are usually objective questions with low difficulty that can be evaluated by the computer immediately. The purpose is to help students focus on learning, test the holding of important knowledge points and prompt students to pay attention.

The second is after the class test and homework. There are usually after class test questions and homework questions after each course. After class test questions are mainly objective questions, sometimes there are a few subjective questions. After students submit their answers by computer, they can immediately get correct and wrong feedback and have analysis and explanation. In this way, it automatically records and evaluates the support and grasp of students' basic knowledge.

\section{CONCLUSION}

In recent years, "MOOC" has developed rapidly in the world. Although it has its limitations, it has obvious advantages in computer courses, especially in the teaching of basic computer courses in application-oriented universities. In the new round of computer basic teaching reform in applied undergraduate colleges, it is necessary to absorb the advantages of MOOC platform course, strictly control teaching resources and do a good job in classroom design. It should form a benign interaction, realize multiple evaluations and form a systematic and comprehensive "MOOC" teaching mode. The quality of computer teaching in applied undergraduate colleges should be fundamentally improved.

\section{REFERENCES}

[1] Yang Y. The Application of Career-Guiding MOOC Course in Undergraduate Colleges[C]// Eighth International Conference on Measuring Technology \& Mechatronics Automation. IEEE, 2016.

[2] Feng L. Research on Blending Teaching and Learning Model of Applied Undergraduate under MOOC Horizon[C]// International Conference on Contemporary Education. 2016.

[3] Brita-Paja J L, Gregorio C, Llana L, et al. Introducing MOOC-like methodologies in a face-to-face undergraduate course: a detailed case study[J]. Interactive Learning Environments, 2018:1-18.

[4] Gold A, Gordon E. Using a Massive Open Online Course (MOOC) for Earth Science Education: Who Did We Teach and What Did We Learn?[C]// Egu General Assembly Conference. EGU General Assembly Conference Abstracts, 2016.

[5] Xudan W, Li J, Junling D, et al. Pondering over College Physics Teaching Reform in Private Colleges in the Trend of MOOC[J]. The Science Education Article Collects, 2016.

[6] Luo L. Research on MOOC-based Undergraduate Individuation Cultivation Model[C]// International Conference on Arts. 2016.

[7] Plangsorn B, Na-Songkhla J, Luetkehans L M. Undergraduate Students' Opinions toward Ubiquitous MOOC for Enhancing Cross-Cultural Competence $[\mathrm{J}]$. World Journal on Educational Technology Current Issues, 2016, 8(3). 